\title{
Natura jedności eklezjalnej a wydarzenia roku 1054
}

\author{
ks. Marian Bendza \\ Katedra Historii Kościoła Powszechnego i Autokefalicznego Kościoła Prawosławnego \\ Chrześcijańska Akademia Teologiczna w Warszawie \\ Polska \\ mbendza@interia.pl
}

Fr. Marian Bendza, The Nature of Ecclesiastic Unity and the Events of 1054, Elpis, 18 2016: 9-20.

\begin{abstract}
This article is supplementary in nature and was not written to give a narrative presentation of the well-known events of the Schism between the East and West, but rather, with the assistance of several remarks and little known details, to enable a new dimension of reflection and discussion on the issues mentioned in this work. In modern historiography, the events of 1054 are treated as an absolute end to the "period of the indivisible unity of the Church." The objective of this article is to reflect on the quality of this unity and the ascertainment that the events described can be acknowledged as a consequence of tendencies already present.

On the other hand, the author demonstrates that Church unity is not a lack of separatist tendencies, but that they are not able to destroy one of the most important signs of ecclesiastical reality - unity. This unity situates the Church in the Divine plan of salvation, thus making it independent of human decisions, disagreements and pride.

A reflection on unity, based on biblical and patristic analysis, also allows us to relate to the events of 1054 in a different manner. Their "schismatic" character, in the light of texts written at the time, rather appears as a heated discussion, in which both interested sides desire to respond to the challenges of their era in cooperation. It was, after all, the great epoch of the Gregorian reforms in the Roman Catholic Church, the "theological Byzantine golden age" and theology that ensured appropriate development.

Therefore, it might be better to treat the "Schism" simply as a division, and in the harsh declarations made by the hierarchs as an expression of care for an appropriate shape of the Church, particularly in the context of the Normans, who were an emerging power and the increasing tendencies of Caesaropapism.

The author does not hide in the conclusion that in the "golden age of Byzantium" the first and most important crack appeared, however, nothing was able to break the unity of the Church...
\end{abstract}

\begin{abstract}
Streszczenie: Niniejszy artykuł ma charakter uzupełniający, nie został więc napisany celem narratywnego przedstawienia powszechnie już znanego przebiegu Wielkiej Schizmy Wschodniej, lecz przy pomocy kilku uwag i ekspozycji kilku mniej znanych szczegółów umożliwić nowy wymiar refleksji, a może wręcz dyskusji nad zagadnieniami, stanowiącymi treść niniejszej pozycji.

Wydarzenia roku 1054 w historiografii uchodzą za jednoznaczne zakończenie „okresu niepodzielnej jedności eklezjalnej”. Celem więc niniejszego artykułu była refleksja nad jakością tej jedności i konstatacja, iż opisane wydarzenia można uznać za konsekwencję tendencji obecnych już wcześniej.

Z drugiej wszakże strony Autor wykazuje, iż jedność Eklezji to nie brak tendencji separatystycznych, lecz nie są one w stanie zniweczyć tego jednego z najistotniejszych znamion rzeczywistości eklezjalnej, jakim jest jedność. Sytuuje ona Eklezję w Bożym Planie Zbawienia, uniezależniając ją od ludzkich decyzji, od przypadków niezgody czy pychy.

Refleksja nad jednością, poparta analiza biblijną i patrystyczną pozwala też w inny sposób odnieść się do wydarzeń roku 1054. Ich „schizmatyckość” w świetle tekstów z epoki, jawi się raczej jako gorąca dyskusja obu zainteresowanych stron, które pragną wspólnie, w sposób duchowy odpowiedzieć na wyzwania ich epoki, epoki reformy gregoriańskiej po stronie rzymskokatolickiej czy „złotego wieku Bizancjum", także teologii zapewniającemu odpowiedni rozwój.

Można więc uznać, iż lepiej nazwać „Schizmę” po prostu podziałem, a ostre wypowiedzi hierarchów uznać za wyraz troski o właściwy kształt Eklezji, zwłaszcza w kontekście rodzącej się potęgi Normanów czy narastających tendencji cezaropapistycznych.

Autor nie ukrywa w konkluzji, iż na okresie „złotego wieku Bizancjum” pojawiła się pierwsza, poważniejsza rysa, jedności kościelnej jednak nic nie jest w stanie naruszyć...
\end{abstract}

Keywords: the Church History, the Orthodox Church, Ecclesiology, Great East-West Schism

Słowa kluczowe: Historia Kościelna, Prawosławie, eklezjologia, Wielka Schizma Wschodnia

Wydarzenia, znane powszechnie pod nazwą Wielkiej Schizmy Wschodniej, rozumiane są powszechnie jako ciąg wydarzeń poddających się narracyjnemu opisowi historycznemu. Przepełnione niewątpliwą plastycznością mogą oddziaływać na wyobraźnię, lecz z uwagi na jednoznacznie zarysowaną perspektywę czasową, nie zajmują obecnie właściwego miejsca w świadomości odbiorców. Ich natura zresztą predestynowała je do tego.

Celem niniejszego artykułu będzie odniesienie się do wskazanego konglomeratu wydarzeń, $\mathrm{z}$ naciskiem wszelako na ich wymiar teologalny, eklezjologiczny. Tak zarysowana refleksja, oscylująca w kierunku dogmatycznym, po- zwoli na prezentację dość powszechnie znanych wydarzeń w innym, niż zazwyczaj, świetle, w innych niż się zwykło przyjmować, odniesieniach.

A jednak we wskazanej refleksji nie zabraknie odniesień historycznych. W ten sposób, niejako w koniunkcji teologia - historia eklezjalna stanie się możliwe jakościowo nowe odczytanie, co zaś za tym idzie, ustosunkowanie się do postaw protagonistów oraz, na ile skromne uwarunkowania artykułu pozwolą, sprostowanie niektóre petryfikowanych tradycją treści.

Niewątpliwym fundamentem takiej refleksji będzie relacja patrystycznych dokumentów pochodzących z X i XI 
stulecia, które w sposób jednoznaczny, a często bardzo plastyczny pozwalają odkrywać nie tylko przebieg wydarzeń, lecz także ponownie odsłonić Tajemnicę Kościoła, tajemnice ukrytą od wieków, lecz przecież wciąż na nowo objawianą!

Takie podejście sugerują też wydarzenia i dokumenty rocznicowe, jak choćby ogłoszona 1 czerwca 2004 roku, w 1050 rocznicę wydarzeń, Deklaracja wspólna, podpisana przez papieża Jana Pawła II i konstantynopolitańskiego patriarchą ekumenicznego, Bartłomieja I. Podczas towarzyszącego podpisaniu Deklaracji spotkania przekazano sobie wzajemny pocałunek pokoju, stwierdzając: „Nasze [scilicet prawosławno - rzymskokatolickie] stosunki powinny odzwierciedlać prawdziwą i głęboką komunię w Chrystusie, która - choć nie jest jeszcze pełna - już teraz nas jednoczy. Z radością bowiem stwierdzamy, że łączy nas tradycja niepodzielonego Kościoła, skupionego wokół misterium Eucharystii" ${ }^{1}$

Już ten niewielki, lecz jakże charakterystyczny fragment, zawiera $\mathrm{w}$ sobie szereg jednoznacznych odniesień eklezjologicznych, których też z uwagi na rangę dokumentu i Osób go podpisujących pomijać nie należy. Zawiera też bardzo popularne, acz nieco, jak się okaże kontrowersyjne, sformułowanie o niepodzielności eklezjalnej pierwszego tysiąclecia chrześcijaństwa. Warto więc zapytać o jakość jedności w odniesieniu do społeczności zwołanych, czyli Eklezji, warto choć pobieżnie wskazać na „rysy” zaistniałe w historycznym rozwoju na Chrystusowym Ciele Mistycznym, warto może wydobyć z ukrycia czynniki mało dotąd w refleksji historiozoficznej uwzględniane, jak np. obecność Normanów i ich znaczenie dla Historii Kościoła.

Wspomniani Hierarchowie wskazując też na „niepełność" relacji interkonfesyjnych ewokują też pytanie o charakter tej „niepełności”.

$\mathrm{Z}$ uwagi na założenia formalne i treściowe artykułu teologicznego, wyczerpująca, wymagająca monograficznego opracowania odpowiedź na wskazane problemy nie jest możliwa. Skupimy się zatem jedynie na kwestii jedności eklezjalnej, kategorii pryncypialnej nie tylko dla eklezjologii jako takiej, lecz przede wszystkim w odniesieniu do wydarzeń roku 1054.

Niech punktem wyjścia tej refleksji stanie się wydarzenie chronologicznie wcześniejsze, też pełne eklezjologicznych odniesień, czyli Deklarację wspólna, (7 grudnia 1966 roku)sygnatariuszami której był papież Paweł VI i patriarcha Konstantynopola, Atenagoras. Tenże dokument w paragrafie trzecim głosi: „Przeto jest rzeczą niezmiennie ważną, by zdawać sobie sprawę $\mathbf{z}$ napięć towarzyszących tamtym wydarzeniom [czyli Wielkiej Schizmie - dopisek i podkreślenie moje, ks. M. B.], które w rezultacie doprowadziły o wiele dalej, /.../ niż to ich autorzy zamierzyli i zdołali przewidzieć"2. Ze słów tych wynika, iż tzw. Wielka Schizma nie była zamiarem członków Kościoła wieku XI, stała się zatem...

\footnotetext{
Deklaracja, Punkt 3.

2 Tekst Deklaracji Acta Apostolicae Sedis, 58 (1966), s. 41. Cytuję za ks. E. Przekop, Rzym - Konstantynopol . Na drogach podziału i pojednania, Olsztyn 1987, s. 49.
}

Hipotetycznych dokończeń tego zdania mogłoby być wiele, co nie zwalnia od próby sformułowania najbardziej adekwatnego wniosku, koherentnego nie tylko ze stanem faktycznym omawianego zagadnienia, lecz także z faktycznie stwierdzonymi przez dokumenty tendencjami jego rozwoju.

Zwrócenie w latach sześćdziesiątych uwagi na niewątpliwe napięcia jedenastowieczne (Deklaracja wcześniejsza) stanowi cenny wyznacznik rozwoju myśli teologicznej dekad następnych, zawartej w Deklaracji późniejszej:

- czy następujące w różnych okresach podziały (bądź przynajmniej „zarysowania”) na eklezjalnie pojmowanym Ciele Chrystusa miały charakter istotowy dla rzeczywistości eklezjologicznej, czy też wyłącznie akcydentalny?

- czy z uwagi na napięcia, wydarzenia roku $1054^{3}$ uznać można za trwałe oddzielenie Wschodu od Zacho$\mathrm{du}^{4}$, a co za tym idzie, uznać zaistniałe wówczas anatemy za obowiązujące oba wyznania, czy też nie?

$\mathrm{Z}$ natury rzeczy, powód zaistnienia artykułu jest więc jednoznaczny: próba pogłębionego spojrzenia na powszechnie znane, lecz może $\mathrm{z}$ tego powodu nieco spłycane kwestie. Cel wydaje się zaś konsekwencją założeń inicjalnych: wygenerowanie nowego progu świadomości odbiorców poprzez ukazanie właściwego charakteru strukturalnego zaistniałych wydarzeń.

\section{Jedna Eklezja zamysłem Chrystusa}

Chyba najważniejszym eklezjologicznie fragmentem ewangelicznym jest tak zwana deklaracja Chrystusowa, dotycząca zaistnienia Eklezji ${ }^{5}$, a zapisana w $M t$ 16,16-18. Jest to jeden $\mathrm{z}$ najbogatszych teologicznie fragmentów, gdzie dostrzec możemy wskazanie wymiaru jakości apostolatu, określenie struktury eklezjalnej, charakter duchownej władzy itp. W omawianym fragmencie nie brak też symboli i obrazów, budzących często gorące dyskusje teologów, a nawet ewokujące polemiki.

Ze wskazanej Deklaracji Pańskiej, dla potrzeb naszej refleksji wyodrębnię passus: oikodomésomou ten ekklesín zbuduję swą społeczność zwołanych (Eklezję).

Domyślne użycie pierwszej osoby liczby pojedynczej ([ego] oikodoméso) i także w liczbie pojedynczej przedstawione dopełnienie (ten ekklesín) wskazuje, iż zamysł chrystusowy dotyczył jednej i tylko jednej Eklezji ${ }^{6}$, która poddana continuum rozwojowemu miała, zgodnie z dalszym zamysłem Deklaracji, dysponować taką mocą, której nie przemogą nawet bramy piekielne. Będzie to więc nie tyle Jedna (una) Eklezja, lecz z uwagi na decyzje Boga - Chrystusa także sola (sama w sobie wyjątkowa) i unica (jedyna).

\footnotetext{
W homiletyczno-katechetycznym przekazie rzymskokatolickim Wielka Schizma Wschodnia jest datą zaistnienia Prawosławia jako wyznania.

4 Tak zresztą uważają klasycy zagadnienia, S. Runciman czy ks. E. Przekop.

5 Czyli fragmentu Mt 16, 16-18;

6 W odniesieniu do widzialnej wspólnoty wierzących stosuje się skądinąd niewiadomego pochodzenia termin Kościół; dla głębszego jednak oddania sensu omawianych zagadnień zastosuję termin Eklezja.
} 
Tę naturalną niezwykłość sugeruje też jakość continuum rozwojowego: będzie ono budowaniem, jak sugeruje $\mathrm{w}$ futurum exactum czasownik oikodoméso. Zawarty w temacie tego słowa rzeczownik oikos (dom) określa też pośrednio zarówno naturę tego budowania, jak i jego efekt. Mocą obecnego w Niej Chrystusa Dom Boga, nawiązujący do jerozolimskiej Świątyni, która jest nie tylko Domem Modlitwy $^{7}$ (Beitbit) lecz i domem dla wszystkich, gdzie nawet wróbel dom swój znajduje, a jaskółka gniazdo8.

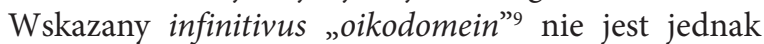
pojęciem jednoznacznym, co potwierdza wydany w dobie międzywojennej słownik Die Religion in Geschichteund Gegenwart $^{10}$, stwierdzający w hasłowej konkluzji, iż w Nowym Testamencie budowanie nie dotyczy wspólnoty, lecz indywidualnej jednostki, która udoskonalana Słowem Bożym, pracą nad sobą, tylko pośrednio wpływa jeno na rzeczywistość wspólnotowego przeżywania wiary, skupiając się raczej na własnej doskonałości.

Wskazany infinitivus domaga się znanego już gramatycznego dopełnienia, które należy uzupełnić podmiotem: Kto jest Autorem budowania? Jedynym słusznym jak się wydaje rozwiązaniem, jest wskazanie na Autora Deklaracji, przekazującego jej treść.

Niektórzy bibliści niemieccy, Kögel i Cremer ${ }^{11}$, skłaniają się jednak ku inaczej określonej Osobie Budowniczego: odwołując się do Starego Testamentu wskazują, iż Budowniczym jest tylko Bóg Ojciec, obdarzający także Swych wyznawców wysokim stopniem aktywności.

Swą wypowiedź uzasadniają stwierdzeniem Apostoła Narodów, iż inicjatywa każdej aktywności duchowej bierze swój początek w principium „aktywności” Adonai.

Ten sam biblijny Autor w Liście do Efezjan posługuje się obrazem domu - Eklezji ${ }^{12} \mathrm{w}$ znaczeniu szczególnym jako Bożego budowania. Wydaje się, że ujęcie takie pomija aktywność człowieka, wydaje się, że zarówno św. Piotr, jak i św. Paweł tak bardzo zdominowani są ideami eschatologicznymi, że pomijają realizowana tu i teraz, hic et nunc, aktywność. Eschatologiczny obraz rozwinie się zwłaszcza po ich męczeńskiej śmierci, gdy bohatersko bronione gruzy świątynne na myśl przywiodą Świątynię Nową, jedynie w wymiarze duchowym uczestniczącej apokaliptycznym Nowym Jeruzalem. Światłem bowiem będzie tam Baranek, „celebransem” Zasiadający na Tronie, a reprezentantami ludzkości 144 tysiące opieczętowanych. W tym wymiarze refleksji apostolskiej, reprezentowanej przez św. Jana Teologa budowanie przybierze eschatologiczny wymiar formowanie jedności z Baronkiem, miedzy sobą i Ojcem.

12 Por. Ph. Vielhauer, Oikodome, Das Bild von Bau In der christlichen Literatur vom Neuen Testament bis Clemens Aleksandrinus, Heidelberg 1939, s. 190.
}

W Deklaracji chrystusowej zda się też pobrzmiewać przesłanie jedności wyrażone przez proroka Jeremiasza: Wiekuisty przyrzeka sąd nad poganami (Jr 12,16), co sugeruje, iż jedyny wymiar podmiotowej jedności z Bogiem i wyznawcami odnaleziony będzie w Izraelu ${ }^{13}$. Wypowiedź ta zawiera w sobie immanentnie obraz Chrystusa jako Kamienia odrzuconego (apedokimasan $)^{14}$ przez budujących, który stał się kamieniem węgła ${ }^{15}$, stąd występuje jako niekwestionowany Autorytet spraw eklezjalnych, wszelako nie jako jedyny Budowniczy i Strażnik Jedności. Syn bowiem zawsze stanowi jedno z Ojcem, obejmując Go Miłością Ducha Świętego.

Odnosząc się zatem do wyjątkowości Jedynej Eklezji nie można zapominać o odniesieniach trynitarnych. Jezus w ten sposób wydaje się przekazywać Swe Obdarowanie przez Ojca innym, acz niżej od Siebie stojącym. Odniesienia starotestamentalne każą dostrzegać w akcie przekazania deklaracji również elementy przymierza.

W istocie, już zaistniała w Edenie Proto Eklezja, ukształtowana w wyniku przyjaznego przestawania Adonai z pierwszymi rodzicami, w obecności których mógł On przechadzać się po rajskich przestrzeniach, co ewokowało ludzką radość Jego Obecności, której nie mąciła nawet nagość, gdyż ludzie ci nie odczuwali wstydu, byli bowiem jeszcze bezgrzeszni.

A jednak Chrystus, mówiąc o budowaniu Swojej Eklezji, zdaje się odnosić do bytu, do fenomenu jakościowo odmiennego. Sytuacja taka jest jednak pozorna.

Wypełniając Prawo i Słowa Prorokó ${ }^{16} \mathrm{~W}$ sposób jednoznaczny powiązał Swą działalność z obecnością judaizmu, kontynuując i wypełniając zbawczy Plan. Tak kontekstualizowana Jego Eklezja będzie wypełnieniem i dopełnieniem misji kapłańskiej, misji Świątyni, sprawiając, iż Abraham odnajduje się w Piotrze, kahał we Wspólnocie Ochrzczonych, Izrael zaś w Ludzie Wybranym Nowego Przymierza ${ }^{17}$.

Nie bez znaczenia jest też użycie futurum exactum, czasu przyszłego dokonanego. Potwierdza on Wolę $\mathrm{Bu}$ downiczego, by doprowadzić dzieło Swe do końca, jednocześnie jednak wskazuje na pewne continuum, pewien

\footnotetext{
13 Por. P. Bonnard, dz. cyt., s. 13.

14 Użyty wyraz należy do terminologii sadowniczej i odnosi się do falsyfikatów. Przywódcy Ludu uznali Mesjasza za falsyfikat, posądzali o fałszywe i zbędne starania, przeto odrzucili Go, biorąc tym samym na siebie ogromna odpowiedzialność. A był On wszak dla Boga najbardziej pożytecznym Budowniczym Bożego dzieła. Na marginesie: odpowiedzialność moralna przedstawicieli Narodu Wybranego, działającego na wyraźne żądanie swych duchowych przewodników, kapłanów i faryzeuszy jest daleko mniejsza, niźli odpowiedzialność „funkcyjnych”.

15 Do tego starotestamentalnego obrazu odwołał się Jezus pośrednio, cytując Stary testament. Por. Mt 21,42; Mk 12,10-11 czy $Ł k ~ 20,17$.

16 Por. Mt 5,17. Prezentacja nauczania Chrystusowego w kontekście wypełnienia Pism w Osobie i działaniu Chrystusa to Leitmotiv Ewangelii wg św. Mateusza. Na Chrystusie spełniły się prorockie zapowiedzi, Chrystus w doskonały sposób wypełnił Prawo. Można powiedzieć, iż w ten sposób także immanentnie zawierają się zasadnicze dwa kierunki rozwoju eklezjalnego: na doktrynie niosącej rys chrystologiczny i na judaistycznej Tradycji, której On jest najwierniejszym Komentatorem.

17 Por. P. Bonnard, dz. cyt., s. 25. Odnosząc się do wskazanej interpretacji Chrystusowego Budowania autor nazywa ją „rewolucyjną,.
} 
rozciągnięty w czasie proces zaistnienia tego nowego „organizmu wiary", którego istoty expressis verbis Zbawca nie podaje, podobnie pomijając milczeniem termin rozpoczęcia tego budowania. Być może nawiązanie do zastanej zarówno przez Chrystusa, jak i apostolskich uczniów kahału umożliwiało odbiorcom wyobrażenie sobie jakościowej jedności i spójności organizacyjnej Dzieła Chrystusowego. Bo niezależnie od wyjątkowości, jest Eklezja w sensie organizacyjnym odwzorowaniem jakości ukształtowanych przez Pełnię Czasów.

Rzeczywistość eklezjalna będzie więc zawsze odwoływać się do Chrystusa, aczkolwiek jako stały proces budowania nie osiągnie na ziemi doskonałości. Taka będzie możliwa dopiero w Królestwie, gdzie Jeruzalem Niebiańskie, którego lampą jest Baranek ${ }^{18}$, stanie się „portem wytchnienia" dla zbawionych.

Rodzi się zatem kwestia bardziej złożona, a dotyczy ona relacji zachodzących pomiędzy ustaleniem starotestamentowego a nowotestamentowego okresu kształtowania się Eklezji. Dla teologii rzymskokatolickiej, ogólnie rzecz ujmując, wydaje się jasne, iż dopiero kontekst ofiary Chrystusa i Zesłanie Ducha Bożego w dzień Pięćdziesiątnicy pozwala na zaistnienie Kościoła par excellence ${ }^{19}$ Wydaje się zatem, iż w ten sposób Stary Testament pełni rolę wyłącznie przygotowawczą, typologiczną ${ }^{20}$.

Takiemu ujęciu sprzeciwia się jednak jakościowa analiza fenomenu kahału. Czy liczący kilka tysięcy lat okres można uznać wyłącznie za czas zapowiedzi? Niewątpliwie tak. Arka Przymierza będzie zawsze typem Sanctissimum, a Arka Noego zapowiedzią konsekracji chrzcielnej.

Istnieją wszelako desygnaty semiologicznie ważniejsze, niż typologia, a do takich zaliczyć można kategorię Ludu Bożego, samookreślanie się Izraela jako Pańskiej trzody, mesjański wymiar wiary, teologię nadziei, regularne praktykowanie pobożności o charakterze biblijnym, instytucjonalna „ochrona” prawdy Bożej itp. Elementem łączącym te desygnaty jest nie tylko wiara, lecz przede wszystkim świadomość człowieka wierzącego, do której odwoływał się Jezus, budując swą Eklezję zwłaszcza przez nauczanie.

Wyznawca judaizmu $\mathrm{w}$ okresie przed zaistnieniem Pełni Czasu świadomość swą budował na podstawach narodowych. Przynależność do Ludu Wybranego była drogą do Wybrania Bożego, spotkania w synagodze zaś uzupełnieniem pielgrzymek do Świątyni. Społeczność wierzących kształtował Adonai niemal bezpośrednio, rytm jej życia duchowego uporządkowany był pielgrzymkami i dźwiękiem sofaru. Adonai, Skała Zbawienia ukazywał jednak coś więcej: nadejście Mesjasza, które miało rozpocząć nową erę.

\footnotetext{
18 Por. Ap 22,5.

19 W obecnym przekazie rzymskokatolickim następuje powszechna skłonność do wskazania Pięćdziesiątnicy jako czasu ujawnienia się już istniejącej Eklezji, milczeniem jednak pokrywa się czas Jej zaistnienia. Deklaracja Jezusowa nie mogła być tym czasem, skoro mówi się tu o Niej w czasie przyszłym. Najpewniejszym do przyjęcia wariantem będzie czas ofiary - tej bezkrwawej i tej na Krzyżu.

20 Por. ks. J. Laska, Kościót, Eklezja, Chrystus, Warszawa 2012, rękopis, s. 26.
}

Jak bardzo nową, tego nie mogły przewidzieć rabinackie umysły. Oczekiwano jasnych, widomych dla wszystkich znaków, zwłaszcza tych ustalonych na podstawie analizy i refleksji biblijnej: oczekiwano zatem spotkania z Eliaszem, rozumiano, że nadal relacje z Bogiem wyznaczać będą pielgrzymki i dźwięk sofaru. I w tym momencie słyszymy: Ty jesteś Piotr, /.../ a na tej skale zbuduję mą Eklezję (Mt 16, 18).

Wyznawca miał świadomość budowy dawidowo salomonowej, odrestaurowywanej właśnie przez Heroda Świątyni, tu jednak okazało się coś znacznie większego, niż Świątynia, Ktoś znacznie większy, niż Salomon ${ }^{21} \ldots$

Deklaracja budowania stanowi również przekazanie dynamizmu chrystusowego $\mathrm{w}$ zaprezentowany proces. W kontekście tego dynamizmu miał następować nowy akt stworzenia Nowego Człowieka i Nowej Rzeczywistości. Rzeczywistość tę w aspekcie związku z Chrystusem doskonale obrazuje krzew winny, którym jest Chrystus, do Niego zaś należą ci, zobrazowani przez latorośle.

Jedność eklezjalna to jedność wielostopniowa i wielozakresowa. Obejmuje więź z Chrystusem i powiązania wiernych między sobą; jedność w łasce i społeczność Słowa; jedność sakramentalną i wierność indywidualną.

Prawosławna wizja jedności eklezjalnej rozumiana jest teologicznie i prawno kanonicznie. Teologiczne pojmowanie jedności bazuje na wyznawaniu tej samej trynitarnej doktryny, sformułowanej wspólnotowo ${ }^{22}$ na siedmiu pierwszych soborach powszechnych. Zgodnie z nauczaniem św. Pawła obecny w całym świecie widzialny Kościół (Eklezja) jest „organizmem” złożonym $\mathrm{z}$,jednostek autokefalicznych", samodzielnych wspólnot wyznaniowych, Eklezji lokalnych, które dopełniając się wzajem tworzą pełnię (pleroma) na fundamencie miłości.

Ważnym wyznacznikiem tej jedności jest koinonia sakramentalna, wsparta integralnym przyjęciem przekazu Objawienia oraz wspólnotową realizacją życia eklezjalnego (zwoływanie zebrań liturgicznych, soborów itp.) ${ }^{23}$.

Omawiana refleksja odwołuje się do biblijnego przekazu eklezjologicznego:

- Jeden Pan, jedna wiara, jeden chrzest $-E f 4,5$;

- choćby my albo anioł z nieba zwiastował co innego, niż myśmy wam przepowiadali, niech będzie przeklęty ( $G a$ 1,8) - jedna jest bowiem Ewangelia, Nauka Pańska.

Potwierdzeniem tego przekazu jest wypowiedź św. Ireneusza ${ }^{24}$ : „Prawdziwy i powszechny Kościół jedną i tę samą wiarę w całym świecie przechowuje".

Jedność w wymiarze sakramentalnym oscyluje jeszcze mocniej w stronę duchowego jej wymiaru. Potwierdzeniem niech będzie cytat: „Weźmijcie Ducha Świętego; którym odpuścicie grzechy, są im odpuszczone, a którym zatrzymacie, są im zatrzymane" ( $20,22-23)$, co pośrednio potwierdza też św. Hilary ${ }^{25}$, „Przez jeden dar sakramentu

\footnotetext{
21 Por. tamże, s. 27.

22 Zasada soborowości, sobornosti.

23 W ujęciu rzymskokatolickim podkreśla się dwa zasadnicze wymiary jedności: jedność wiary i sakramentów.

${ }_{24}$ Adversushaereses 1.1, capitulum 10.

25 Commentarium in Psalmos 121, n. 5).
} 
wszyscy jesteśmy zjednoczeni”"26. Można zatem powiedzieć, iż widzialna jedność stanowi odbicie wewnętrznej, niewidzialnej jedności w Duchu Świętym. Jedność ta obejmuje przede wszystkim więź z Chrystusem, siostrami i braćmi, a wydaje się być nierozerwalną.

W wyniku zderzenia dwu koncepcji - eklezjologii sakramentalnej (zwłaszcza eucharystycznej)27 i eklezjologii uniwersalnej ${ }^{28}$ jako element wspólny obu koncepcji jawi się zjednoczenie eucharystyczne, communio z Chrystusem poprzez ucztę i ofiarę. Eucharystia, zwieńczenie inicjacji chrześcijańskiej stanowi bowiem podstawę zaistnienia eklezjalnego, aczkolwiek życie sakramentalne w uwarunkowaniach eklezjalnych stanowi swoiste novum wiary, nabierając zarazem integrującego wymiaru. Eklezja bowiem to stale kontynuowana, wiecznie trwająca Eucharystia ${ }^{29}$, stale umacniana przez Chrystusa jedność.

Nie bez znaczenia jest jednak odniesienie antropologiczne, wyraźne zaznaczone w omawianym passusie $M t$ 16,18: „terenem” budowy Eklezji jest człowiek. Piotr - Skała wydaje się tu być reprezentantem rodzaju ludzkiego, któremu niejako powierza się misterium budowania.

W ten sposób Chrystus wysuwa na plan pierwszy zagadnienie osoby jako „wykonawczyni” ukonstytuowanego przez Chrystusa „zamiaru eklezjalnego”. Odwołując się do Boecjusza $^{30}$, osoba to naturae rationalis indiwidua substantia, czyli jednostkowa forma istnienia natury rozumnej. Łaciński przymiotnik individuus oznacza nie tylko jednostkę oddzielną, lecz przede wszystkim autonomiczną. A więc Chrystus, budując Eklezję sprawia, iż pozostaje Ona Jego „własnością”, aczkolwiek przekazana ludziom skłonnym do wynikających z personalizmu indywidualizacji, autonomizacji czy nawet tendencji separatystycznych.

Jak widać, jedności eklezjalnej przeciwstawiono niejako „jedność autonomiczną”, „jedność bytów autonomicznych". Zetknięcie z misterium Chrystusa sprawia, iż pozorny paradoks jedności w separacji nabiera znamion logicznych: autonomiczna osoba ma prawo wejść w misterium Jedności Bożej, uczestniczy bowiem w ten sposób w Trójjedyności i rozwija swą osobowość. Nie zapominajmy, iż rzeczywistość trynitarna jako szczyt egzystencji osobowej również charakteryzuje się autonomicznością - czyż

\footnotetext{
26 Jak się wydaje warto przytoczyć pochodzący z początków XX stulecia komentarz rzymskokatolicki: [Taki stan jedności] wynika z natury stowarzyszenia religijnego widzialnego, jakim jest Kościół. Sakramenty święte są to bowiem widzialne środki uświęcające, a kto z nich godnie korzysta, może być pewnym, że zarazem udziela mu Bóg łaski niewidzialnej; gdyby zaś istniały przeróżne rodzaje tych środków, nikt by nie wiedział, z których ma korzystać i musiałby dla pewności używać wszystkie albo też uważać za rzecz całkiem obojętną, czy np. w tej lub owej postaci albo też bez żadnej postaci widzialnej przyjmuje Pana Jezusa w Najświętszym Sakramencie Ołtarza”. Por. ks. J. Tylka, Dogmatyka katolicka [wersja internetowa].

27 Eklezjologię eucharystyczną prezentowali Ojcowie Kościoła Z pierwszych wieków myśli wschodniej, jak na przykład św. Ignacy Antiocheński, a z reprezentantów myśli zachodniej św. Hipolit Rzymski czy św. Cyprian z Kartaginy.

28 Zaistniałą w myśli wschodniej w wyniku inspiracji teologii rzymskokatolickiej.

29 Por. P. Evdokimov, Prawosławie, Warszawa 1986, s. 164

30 Boecjusz 480-524), rzymski filozof, swą słynną definicję osoby zawarł w dziele De persona Christi (PL 64, 1343)
}

nie mówimy o Hipostazie Boga Ojca, Hipostazie Syna czy Hipostazie Ducha Świętego. A zatem eklezjalne uczestnictwo w Tajemnicy Boga jest nacechowane autonomizmem, pomimo którego Bóg tworzy z wierzącym jedność, pozwalając mu na zachowanie osobowej wolności i transparentności wyborów.

W autonomiczności wolnej i rozumnej osoby tłumaczy się zatem wskazana powyżej jakość „trójstopniowej” jedności, jedyności i wyjątkowości eklezjalnej, która jednak z zamiaru Bożego się nie rozpada, lecz egzystuje w sposób dostępny zarówno dla Boga, jak i dla człowieka.

Dbałość o jakość tej jedności autonomicznej nie jest jednak bez znaczenia, z uwagi na fluktuacje i dynamizm eklezjalny. Można powiedzieć, iż wybory ludzkie streszczają się w przychodzeniu, odchodzeniu, powrocie, egoizmie nawet. Taką jakość wyborów odnajdujemy więc de natura rei w organizmach eklezjalnych, a wywołują one nawet spory i dyskusje odnośnie do sposobu funkcjonowania Eklezji: czy modlitwa, czy praca charytatywna czy nauczanie? Wszystkie trzy wydają się i są w istocie eklezjalnymi elementami konstytutywnymi, przeto Jezus ostrzega: Ubogich zawsze macie między sobą, Mnie nie zawsze macie $(M t 26,11)^{31}$. Oznacza to, iż więź z Chrystusem może zostać zerwana, także ze szkodą dla wymiaru eklezjalnego egzystencji ludzkiej, podczas gdy ubodzy i związana z nimi działalność charytatywna, acz niewątpliwie cenna i ważna, nie jest jednak tak samo istotna dla rzeczywistości eklezjalnej jak na przykład życie sakramentalne czy przekaz Nauki Pańskiej. Co więcej, ujęcie takie uwzględnia również wskazaną powyżej charakterystyczną dla rzeczywistości ludzkiej możliwość decyzyjną: odejścia bądź powrotu.

A zatem continuum rozwojowe Eklezji naznaczone jest faktycznymi fluktuacjami. Wolna wola człowieka może spowodować opowiedzenie się za Chrystusem, albo tė̇ wybór rzeczy Jemu przeciwnych. Czy i wy odejść chcecie? - zdaje się nieustannie pytać Bóg. A pytanie to jest wciąż powtarzającym się weryfikatorem dynamizmu życia chrześcijańskiego, a także chwil funkcjonowania Eklezji „poza Chrystusem", gdzie mocniej dojść może do głosu ludzki egoizmem, niechęć, brak życzliwości lub duchowe oddalenie od Chrystusowego Ducha ${ }^{32}$...

Lecz jedność jest zawsze odnawialna w Duchu, bowiem, jak mówi ks. H. Paprocki ${ }^{33}$, wypływa ona w sposób konieczny z jedności Bożej; Eklezja nie jest bowiem wielością osób w ich osobowej oddzielności, ale jednością Bożej Łaski, żyjącej w wielości rozumnych stworzeń, przed łaską tą się korzących.

Jak zatem wygląda doniosły wymiar jedności eklezjalnej z punktu widzenia doktrynalnego?

\footnotetext{
31 Por. też analogicznie: $M k$ 14, 7 i J 12, 8.

32 Bardzo interesującą, acz krótką i chyba podzielaną przez większość wyznawców Chrystusa charakterystykę eklezjalną zawarł S. Runciman w swojej Schizmie Wschodniej: „Takt i powściągliwość są w najlepszym razie rzadko spotykane w kołach kościelnych, a jeśli ich brak jest spowodowany ignorancją, wyniki stają się tragiczne" (por. Schizma Wschodnia, przekład Jan Gawroński, Warszawa 1963, s. 20. Zarówno autor tej charakterystyki, jak i jej odbiorca dostrzeże z łatwością, iż przytoczonymi słowami można też scharakteryzować zagadnienia roku 1054.

33 W artykule Granice Kościoła, www.prawosławie.pl .
} 
Wydaje się ona kategorią absolutną, a wymiar ten zapewnia jedna wiara, jeden chrzest, jedna Eucharystia, a zwłaszcza Jeden Chrystus. Jedna jest też Prawda i jedno Królestwo, do którego się ona odnosi. Tak kontekstualizowana, jest Eklezja wyjątkowym fenomenem jedynej, niepodzielnej, acz złożonej z autonomicznych „elementów", wspólnoty, gdzie Bóg jest wszystkim we wszystkich. Eklezja, w wyniku bezpośredniego „dotknięcia” dłoni Zbawiciela, wznosi się na dwu fundamentach - miłości do Boga i do bliźniego, a w ten sposób stanowi rzeczywistość w jednakowej mierze soteriologiczną, jak i eschatologiczną.

Jedność i związana z nią wyjątkowość eklezjalna ma stanowić szczególne pole działania Chrystusa zjednoczonego z Ojcem, od Którego otrzymał wszelką władzę na Niebie i ziemi ${ }^{34}$ poprzez sakramenty spełnia zleconą Mu przez Ojca misję kapłańskiego Pośrednictwa Łaski.

Gwarantem jedności jest też Duch Święty - Eklezja to społeczność zwołana przez Ducha, nieustannie działającego i oddziałującego na bieg wydarzeń eklezjalnych ${ }^{35}$. Dzięki Niemu proroctwo, asceza, mistyka, charyzmaty ubogacają rzeczywistość eklezjalną i wyznaczają autentyczne szlaki zbawienia i uświęcenia ${ }^{36}$.

Jedno też jest natchnienie tegoż Ducha, dzięki któremu zaistniało Pismo. Jego Autor natchniony nie otrzymał nic ponad własne ukształtowanie edukacyjne, został jednakże uzdolniony do wiarygodnego przekazu Prawdy Bożej.

Duch Święty formuje też Ciało Chrystusowe - Eklezję widzialną i Kościół Niewidzialny, współdziałając w rzeczywistości sakramentalnej i kontynuując chrystusowe Budowanie. Jak mówi ks. Paprocki: „tam, dokąd zstępuje Duch, istnieje też Kościół na zasadzie Ciała", a Duch warunkuje pełnię Bożego życia ${ }^{37}$. Dzięki temu jedna jest też wiara...

Jeden chrzest..

I jedna nadzieja Eschatonu.

\section{Jedność eklezjalna w continuum rozwoju}

Osoba ludzka stwarza swą obecnością i uczestnictwem w Misterium Boga możliwość zaistnienia widzialnej Eklezji $\mathrm{w}$ wymiarze czasowym, temporalnym, zarysowaną powyżej bogatą rzeczywistość doktrynalną „zderzając” z uwarunkowaniami doczesności. Bardzo wcześnie, bo zasadniczo od czasów apostolskich, a na pewno od IV stulecia, dzieje Eklezji zostały naznaczone, by nie rzec, zdominowane ludzkimi fluktuacjami: nie tylko indywidualny grzech, lecz spektakularne i brzemienne w skutkach wydarzenia, często nie związane bezpośrednio z życiem eklezjalnym (np. przeniesienie stolicy cesarskiej z Rzymu nad Bosfor) skutkowały nie tylko zmianami mentalności, lecz skłaniały do generowania legendarnych niekiedy odniesień, mają-

\footnotetext{
34 Por. Mt 28,18;

35 I On też jednak może być wraz z Chrystusem odepchnięty...

36 Por. ks. J. Paprocki, art. cyt., [z uwagi na wersję internetową nie podaję stron).

37 Tamże
}

cych legitymizować taki a nie inny, zarysowany przez ludzi, stan rzeczy.

Bieg pierwszych dziesięciu wieków chrześcijaństwa, w późniejszej historiografii ${ }^{38}$ postrzegany jest jako czas „chrześcijaństwa niepodzielonego". Przyjmując rzecz nawet $\mathrm{w}$ dużym skrócie nie możemy całkowicie się z tym zgodzić - przedstawione bowiem wydarzenia uzasadnia, iz faktyczny rozłam stanowił już w czasach apostolskich siłę rozwojową Eklezji. siła ta dała znać o sobie w drugim tysiącleciu, w którym uwzględniane zresztą przez Chrystusa elementy autonomizacji personalistycznej, wysuwają się niejako na plan pierwszy. Dzieje powrotu i pracy nad obniżeniem poziomu wpływu fluktuacyjnego modelu eklezjalnej egzystencji zastąpiono „walką" sacrum z tym, co światowe, ludzkie. Mówiąc nade obrazowo, na początku XI stulecia pokora i Kenoza Chrystusa miała się zetknąć $\mathrm{z}$ tendencjami prostych reguł kariery i dbałości o siebie i rodzinę. Zarysowane fluktuacje dotyczą zasadniczo dwu zagadnień: prymatu obu stolic i jakości odniesień w kontekście zachowania i postrzegania jedności.

To prawda, że pierwsze tysiąclecie $\mathrm{z}$ uwagi na obecność „pobożności pneumatologicznej”, nie dysponowało w takim stopniu odniesieniami separatystycznymi, jak tysiąclecie następne. Niewątpliwie elementem spajającym mogła też być qualitas wynikania widzialnego wymiaru Eklezji z niepodzielonego judaizmu ${ }^{39}$ i ukierunkowania ku widzialnemu reprezentantowi Chrystusa ${ }^{40}$. W drugim tysiącleciu, zwłaszcza po splądrowaniu Konstantynopola w roku 1204, ostatecznym zdobyciu go i zburzeniu w 1453, do głosu doszły elementy wrogości, resentymentów, zakłócając istniejącą ideę jednoczącą Wschód z Zachodem.

Jak widać, konstytutywny element eklezjalny, jedność, zachowywano w równej mierze tak w pierwszym, jak i w drugim tysiącleciu, jednakże oddziaływania antropologiczne doprowadziły do „personalistycznej dominanty separacji", związanej de natura rei z osobą ludzką, tworzącą nową jakość uwarunkowań.

Najbardziej widomy, a jednocześnie najbardziej nas interesujący jest separatyzm Wschodu i Zachodu, doprowadzający w rezultacie do „schizmy” patriarchy Cerulariusza jako ostatecznego przypieczętowania wskazanych, istniejących od wieków tendencji. Taki stan rzeczy uznać można za „preparację” stanu późniejszego, stan u wyjątkowego spolaryzowania.

\footnotetext{
38 Zwłaszcza historiografii starokatolickiej

39 Którego wyznawcy z uwagi na obecność w środowisku pogańskim również mieli poczucie „odcięcia” (sekty), jaką powodował fakt Wybrania, a zwłaszcza monoteistycznego wymiaru wyznawanej wiary.

40 Reprezentacja podyktowana była uwarunkowaniami świeckiej historii - najważniejszymi patriarchatami stały się patriarchaty stołeczne, mimo że pozostałe trzy uświęcone były bezpośrednią działalnością apostolską, a Jerozolimę wywyższała nawet obecność Chrystusa. Na marginesie dodajmy, iż patriarchat jerozolimski od czasów patriarchy Focjusza i papieża Mikołaja I nie był uznawany w katolicyzmie rzymskim za Matkę Patriarchatów z uwagi na fakt, iż uwarunkowania cesarstwa zmieniły nazwę Jerozolimy na Aelia Capitolina. Nie było zatem Jerozolimy, nie mogło być Jerozolimskiego Patriarchatu. Nie oznaczało to, rzecz jasna, negacji Miasta Świętego jako miejsca działalności Pańskiej, chodziło raczej o ujęcie jurydyczne, nie zaś ideowe, nie ulegające wątpliwości..
} 
Nawet pobieżna analiza każe widzieć Eklezję Wschodu jako Eklezję cesarską, podczas gdy rzymska wydaje się być Eklezją papieską. U źródeł dwu różnych koncepcji eklezjologicznych niewątpliwie znajduje się fakt przeniesienia w roku 330 stolicy Imperium do Konstantynopola, położonego na granicy dwu kontynentów, miasta o ogromnym znaczeniu strategicznym i gospodarczym ${ }^{41}$. Pozostała po stronie zachodniej ziemia stała się terenem inwazji obcych ludów, miejscem oddziaływania obcych idei czy prób tworzenia nowej metodologii teologicznej. A zatem nastąpiła sytuacja konfrontacyjna: wielkość versus pogrobowe starożytnej świetności. Naturalną tendencją była zatem oscylacja wschodnia.

Oscylacji tej nie można było nie uwzględniać w refleksji teologicznej: skoro Konstantynopol, miejsce czterech soborów, przewyższa świetnością Rzym schyłku starożytności ${ }^{42}$, niewątpliwie winien zająć również w wymiarze eklezjologicznym to miejsce, które mu przypadło w udziale drogą decyzji politycznych.

Zakończony w roku 381 sobór konstantynopolitański I, w trzecim kanonie postanawia, iż stolica nad Bosforem ma jednak zajmować drugie po Rzymie miejsce, $\mathrm{z}$ uwagi na tradycję, jakość oddziaływania i długotrwałość istnienia Romy ${ }^{43}$. Takie podejście nie miało na celu poniżenia nowej stolicy, lecz uznanie sytuacji faktycznej, uwarunkowanej historycznie.

Pierwszeństwo Starego Rzymu potwierdził też kanon 28 soboru chalcedońskiego $\mathrm{z}$ uzupełnieniem jednak, iż uprzywilejowaniem cieszyć się mają obie stolice w tej samej mierze ${ }^{44}$.

Taka sytuacja już na początku rodzi problemy doktrynalne i spory ${ }^{45}$ kulturowe, liturgiczne i organizacyjne. Chodzi o praktyki religijne, celibat... Dystans zwiększały też różnice językowe ${ }^{46}$ i niemal „klasyczny” spór o Filioque...

Spory te przeradzały się w różne formy rywalizacji papiesko - patriarszej w odniesieniu do rozwijającego się europejskiego chrześcijaństwa, lecz nie dotykały istoty Eklezji, a tą była jedność.

Przejawiała się ona zresztą $\mathrm{w}$ wymiarze widzialnym: święci Cyryl i Metody wysłani przez cesarze bizantyjskiego do Słowian poddali swą posługę misyjną pod przewodnictwo papieża, a Bruno z Kwerfurtu, realizując misję wśród Pieczyngów, korzystał z pomocy księcia ruskiego, ochrzczonego w obrządku greckim...

Można powiedzieć, iż zarysowana powyżej idea jedności istnieje obok tych rozłamów, które już to w kategorii wydarzeń, już to tendencji skutecznie odzwierciedlają się na Mistycznym Ciele Chrystusa. Nie była to jednak schizma,

\footnotetext{
41 Por. ks. E. Przekop, Rzym - Konstantynopol. Na drogach podziału i pojednania, Olsztyn 1987, s. 17.

42 Zwróćmy uwagę, iż na terenie Urbis Romaenie odbył się żaden sobór powszechny.

43 Por. S. Runciman, dz. cyt., s. 22. Por. także ks. E. Przekop, Rzym..., s. 17. 44 Por. tamże.

45 Istniejące spory sankcjonowano dość rozpowszechniona legendą: Eklezję zachodnią założył św. Piotr, wschodnią, św. Andrzej. Obaj, jako bracia musieli się kłócić, skoro to właśnie Piotr zapytał Chrystusa o jakość przebaczania (por. ).

46 Swoista kością niezgody były języki słowiańskie, używane podczas działalności misyjnej.
}

nie był nawet rozłam, lecz załamanie wcześniejszego stanu relacji, nie zaś tych relacji zerwanie ${ }^{47}$.

Świadomość tego rozłamu była obecna wśród wyznawców już na początku XI stulecia. I oni dostrzegali, iż preferowana jedność nie była monolitem, nie była rzeźbą wykonaną w jednej, niepodzielonej bryle złota. Potwierdzenie takiego stanu rzeczy znajdziemy w zachowanym dokumencie antykwariusza bizantyjskiego, Nicetasa z Nicei o bardzo znamiennym tytule: Jakiego czasu i z powodu jakich zbrodni Eklezja Rzymska odsunęła się od Eklezji Konstantynopolitańskiej? ${ }^{48}$

W tym dość obszernym dziele autor wskazuje szereg przypadków schizm i rozłamów, wywodzących się właśnie z pierwszego tysiąclecia. Wskażmy najważniejsze:

a) za papieża Leona Wielkiego „patriarcha konstantynopolitański omal nie postradał swych stolic z powody listu papieskiego do Anatolii”"49. - W ten dość mało precyzyjny sposób odwołuje się autor do sporu dogmatycznego na gruncie monofizytyzmu i wysłanego w tej sprawie do patriarchy Konstantynopola dokumentu Tomus ad Flavianum. Patriarcha Flawian był zgodny z papieżem, iż Chrystus dysponował dwiema naturami, acz jedną Osobą, aczkolwiek przeciwstawiał się takiemu stanowi rzeczy opat Eutyches, którego w rezultacie odwołano z urzędu. Z uwagi na narastającą sytuację konfliktu, cesarz Teodozjusz zwołał w roku 499 sobór do Efezu, któremu przewodniczył patriarcha Dioskur, a Flawiana odwołano z urzędu i w ciągu trzech dni zamęczono.

Zaprezentowane przez papieża Leona I formuły dogmatyczne okazały się bardziej precyzyjne, niż refleksja wschodnia, reprezentowana choćby przez Cyryla z Aleksandrii, który Osobę Chrystusa opisywał za pomocą dwu terminów: hipostaza-fizys - ciało. Leon Wielkie zastosował trzy terminy: słowo (Osoba Boska) i dwie natury - boska i ludzka. Taki stan rzeczy przedstawia w Tomosie, odwołując się wyłącznie do Pisma świętego i do formalnie pojmowanej dogmatyki łacińskiej od Tertuliana po błogosławionego Augustyna z Hippony.

b) za cesarza Zenona miała miejsce separacja akacjańska $^{50}$, czyli kontynuacja sporu monofizyckiego. Chodzi tu o trwający w latach 484-519 rozłam między Wschodem a Zachodem, którego przyczyną były opory części chrześcijaństwa wschodniego przed przyjęciem kanonów czwartego soboru powszechnego. Ważnym dokumentem z tego okresu jest Henotikon, czyli Akt Jedności, który za podstawy wiary uznawał jedynie orzeczenia pierwszych

\footnotetext{
47 W ten sposób mówiąc o separacji akacjańskiej czy schizmie focjańskiej nie powinniśmy stosować kryteriów odnoszących się na przykład do separacji reformacyjnych doby odrodzenia. Decyzja ks. M. Lutra czy innych reformatorów odwoływała się zresztą do wykoncypowanych przez nich modeli eklezjalnych, nieznanych wcześniejszym wiekom. Na podstawie oddziaływań idei jedności nie podejmowano walki z patriarchatem Rzymskim, lecz jedynie z nim dyskutowano.

48 Tekst zachowany w języku łacińskim (Quibustemporibus et quorum crimanationum causa a Const. Ecclesia sejunxeritse Romanorum Ecclesia), PG 120, 713-720. Choć dokument jest w istocie frapujący, jednak jego autorstwo nie jest pewne. Dzieła nie napisał raczej wierny cesarzowi Nicetas Chomiates (1155-1215), lecz raczej któryś z historyków zachodnich.

49 Por. tamże, PG 120,716

50 Tamże
} 
trzech soborów, nakładając anatemę na myślących inaczej. Połączenie się Ortodoksji z monofizytami oznaczało przeciwstawienie się papieżowi rzymskiemu. „Schizma” ta zakończyła się dość szybko z chwila przyjęcia przez nowego cesarza Justyna I orzeczeń soboru w Chalcedonie.

c) „Za Focjusza wielka się schizma poczyniła, potem wszelako unia nastała. Za czasów Jana, Pontyfeksa ${ }^{51}$ rzymskiego, przestępstwa wszelakie rozliczne przeciw Rzymianom" się zdarzały, a pomimo soborów za Sergiusza patriarchy ponownie schizma się uczyniła ${ }^{52}$.

d) O wiele później za czasów rządów Monomacha i patriarchy Carogrodu, Cerulariusza nastąpiła całkowita separacja, gdyż na Wschodzie przypominano dawniejsze konflikty $\mathrm{z}$ łacinnikami, w akcie zemsty doprowadzając do wymazania imienia papieża ze świętego dyptychu wschodniego ${ }^{53}$.

Na temat patriarchy Focjusza wiele już napisano, więc $\mathrm{w}$ artykule o charakterze przyczynkowym wystarczy jedynie zasygnalizowanie, czasy patriarchy Cerulariusza są zaś przedmiotem naszej refleksji.

Zwróćmy uwagę, iż ten bardzo skrótowo zaprezentowany rozwój wydarzeń wykazuje tendencję wzrostową, jeśli chodzi o zasięg w późniejszej świadomości historycznej, aczkolwiek ani okrucieństwa, ani też braku zrozumienia po obu stronach „konfliktu” zauważyć nie można. Warto też mieć na względzie, iż okres pierwszego tysiąclecia jako czas kształtowania się refleksji dogmatycznej, musiał z natury rzeczy obfitować w rozliczne sposoby ujęcia różnych, zwłaszcza chrystologicznych zagadnień, stanowiących wszak fundament wyznawanej wiary. Nie oznaczało to jednak, powtórzmy raz jeszcze, zaplanowanej chęci dokonania podziału innego, niż się w sposób naturalny wyłonił.

Niemniej, choćby na podstawie korespondencji czy innych dokumentów z epoki, zaistniałemu podziałowi nie można zaprzeczyć. Warto jednak na początku zapytać o jakość tegoż podziału.

Znany specjalista w dziedzinie Ortodoksji, prof. Obolensky w różnych sytuacjach powtarza, iż istotnym powodem tego podziału były wielkie aspiracje obu stron. Papieże rzymscy, zwolennicy bardzo owocnie rozwijającej się wtedy reformy gregoriańskiej starali się, na podstawie zresztą wcześniejszych praktyk, akceptowanych także przez Wschód, być nie tylko głosem doradczym, lecz także dominować myślenie wschodnie zarówno w sferze wiary, jak i mentalności. Wschód z kolei, przeżywający niewątpliwy czas prosperity, także $\mathrm{w}$ znaczeniu teologicznym, nie widział powodu, dla którego należało się wyrzekać pierwszeństwa.

Chciałbym jednak z całą mocą podkreślić, iż zarysowane odniesienia nie były parexcellence schizmą, rozumianą w sensie ideowego rozdziału wierzących czy autonomizującego się ruchu bądź tendencji kreowania odrębnego organizmu o charakterze eklezjalnym. Żadnego z protagonistów wydarzeń nie można też przypisać do grona schi-

\footnotetext{
51 Papieża

52 Por. Nicetas, dz. cyt., PG 120, 717.

53 Por. tamże
}

zmatyków, jako złączonych jedną tajemnicą Chrztu, żaden też nie miał na uwadze generowania podziałów, spór często zamykając w sferze prywatności. Nie bez znaczenia jest też fakt, iż najpewniej był to podział zaistniały de facto, z uwagi na jakość postawy mentalnej wyznawców, nie był zaś podziałem, a tym bardziej schizmą de iure, czyli skutkującą kanonicznie ${ }^{54}$.

Za bardzo charakterystyczny $\mathrm{w}$ tej kwestii uznać można mało znany, napisany piękną greką list „Pańskiego" ${ }^{35}$ patriarchy weneckiego do patriarchy antiocheńskie$\mathrm{go}^{56}$. Odwołanie się do tego dokumentu nie tylko pozwoli na wzbogacenie znajomości materiału epistolarnego spoza kancelarii papieskiej, patriarszej czy cesarskiej, lecz w nieco inny sposób umożliwi też prezentację interesującego nas problemu.

Wspomniane pismo rozpoczyna się wstępem określającym jednoznacznie jego charakter i odniesienia: „Spieszę ze słowem napomnienia, zachowując wszelako cały szacunek i cześć w odniesieniu do Eklezji Twojej, która naszej matki, Eklezji Rzymskiej za siostrę uchodzi ${ }^{57}$, Wszelako, dzięki zasługom Założyciela ${ }^{58}$, św. Piotra, Księcia Apostołów za drugą winna uchodzić. To jednak pominąwszy, sława pobożności Twojej, wiary i dobrych uczynków, sama $\mathrm{z}$ siebie chwałę Twą roztacza, skłaniając nas do pokornego złożenia Tobie hołdu, zwłaszcza że postępujesz drogami Pana i śladami Jego kroczysz"59.

Patriarcha wenecki nie omieszka wytknąć, iż pomimo tak pobożnego patriarchy wschodniego „trzymacie

\footnotetext{
54 Nie bez znaczenia jest też fakt, iż obie strony zachowywały się najczęściej w sposób spokojny i umiarkowany.

55 W oryginale łacińskim widnieje tytuł autora Dominici Patriarchae, czyli w dosłownym tłumaczeniu Patriarchy Pańskiego. Tradycja włoska przed imieniem patriarchy stawia analogiczny tytuł monsignore (w dosłownym przekładzie mój pan), używanym wszelako dopiero od XV stulecia. Być może chodzi zatem o jakiegoś mało znanego patriarchy imieniem Dominik. (por. też przypis następny).

56 Epistola Dominici, patriarchae Venetiarum ad Antiochae patriarcham, PG 120, 751-756. Rzymskokatolicki patriarchat Wenecji, gdyż taka po dziś dzień obowiązuje oficjalna nazwa, utworzono w roku 774 jako niewielką diecezję, z uwagi na znaczenie miasta przyznając biskupom katedry św. Marka honorowy tytuł patriarchy, który jedna na początku XI stulecia zarzucono. W roku 1091, a więc w epoce zaistnienia omawianego dokumentu, została utworzona diecezja Castello, która połączyła się z istniejącym od VI stulecia patriarchatem Grado w roku 1451, tworząc w ten sposób jeden organizm administracyjny i przywracając oficjalne używanie tytułu patriarchy. W związku z czym rodzą się dwie wątpliwości: czy cytowany, jakże ważny w swej treści dokument pochodzi z epoki, mimo że za taki uznany został przez redaktorów Patrologii Migne’a, a także, czy zatytułowanie go w przytoczony sposób może wynikać z ingerencji redak-
} torskiej, nie uwzględniającej historycznego aspektu zagadnienia.

57 Adelfe gnoridzetai. Stylistykę Listu uzasadnia postawa autora: „Aczkolwiek godność moja, w świętości Ducha miły mi Bracie (hierata te pneumatike adelphe), nie tylko stawia mnie na równi z patriarchami, lecz czyni też równym apostołom najwyższym kapłanem Boga. /./ Zaprawdę, od lat dziecięcych aż po późną starość pogrążony byłem w tekstach świętych, nigdy nie pragnąc znać niczego ni słyszeć o niczym, póki nie zostałem mianowany weneckim patriarchą". Epist.Dominici 3, PG 120, 756.

58 Zgodnie z teologią wschodnią założycielem patriarchatu antiocheńskiego był św. Piotr, ten sam, którego Zachód uważa za założyciela Stolicy Apostolskiej.

59 Epist.Dominici 1. PG 120, 752. Nie postrzegajmy cytowanej wypowiedzi w kategorii ironicznej. Jest to po prostu dokument epoki uwarunkowany mentalnością, tradycją, teologiczna metodologią. W związku z tym nie jest to na pewno pismo polemiczne. 
się z dala od waszych wcześniejszych przewodników, bezwstydnie sprzeciwiając się świętym i apostolskim praktykom. $\mathrm{Z}$ tego powodu to, co uważa się u Was za budowanie, jest nie tylko burzeniem tego, co wcześniej zbudowano, lecz nawet odwróceniem się od samego fundamentu. Nadaremnie tedy Piotr i Paweł zwiastowali w Italii, jeśli Eklezja Wschodnia dobrowolnie od przywilejów Prawdy się uwalnia". A do tej Prawdy nie ma innej drogi, jak tylko będąc uczestnikiem Ciała i Krwi Pańskiej, co zresztą sam Chrystus potwierdza ${ }^{60}$.

O tym, że patriarchat wenecki jest pojmowany wyłącznie honorowo świadczy starożytna tradycja obecności wyłącznie ograniczonej liczby patriarchatów pięciu, albowiem tyle jest zmysłów w ciele człowieka ${ }^{61}$. Patriarchaty te w ujęciu autora Listu nie są sobie równe, albowiem różne miano metropolici ich noszą, co więcej, zrównanie tych patriarchatów uznać można za jest „nadużycie”. I tak:

- dla Rzymu i Aleksandrii arcykapłanem (archiereus) jest Papas

- dla Konstantynopola i Jerozolimy - archiepiskopos,

- Antiochia zaś została pominięta ${ }^{62}$.

A Głową tego Ciała, złożonego z wielu członków, jest Chrystus.

Dlaczego jednak arcybiskup Konstantynopola posługuje się tytułem patriarchy? Bo zasiada po prawicy najdostojniejszego papieża (makaritou Papas) i podobnie, jak pierwszemu diakonowi przysługuje tytuł archidiakona, tak pierwszemu po papieżu rzymskim tytuł Patriarchy.

Z uwagi na tak „antropomorficznie” zarysowaną koncepcję patriarchatów, czy można wprowadzać jeszcze patriarchat szósty?

Wasi wierni, bardzo święty patriarcho ortodoksów, nazywani bywają często „kiepskosławni” (kakódoxoi), co z pewnością uraża, bo płynie od złych ludzi, podczas gdy deklaracja patriarchy znad Lido jest jak najbardziej pozytywna i na Ortodoksję otwarta. Ma to potwierdzić przytoczona opinia nadawcy Listu, iż doktryna Ortodoksów jest prawidłowa, możliwa do akceptacji także przez innych chrześcijan. Wszak obie Eklezje stanowią dziedzictwo świętych Piotra i Pawła. A co od Apostołów przyjęte i przez nich do doskonałości doprowadzone, prawdziwej pobożności ma służyćc ${ }^{63}$.

\section{Eucharystia podstawą eklezjalnej jedności}

Zanim jednak doszło do wspomnianych wydarzeń, także ze strony rzymskokatolickiej płynęły próby pojednania. Wspomniany już anonimowy patriarcha znad weneckiego Lido, preferując jedność w różnorodności i harmo-

\footnotetext{
60 Jeśli nie będziecie spożywać Ciała Syna Człowieczego, nie będziecie mieli życia w sobie (J 6,53). Por. Epist. Dominici4, PG 120,753.

61 Por. Epist. Dominici 4; PG 120,760.

62 Por. Epist.Dominici 3; PG 120, 757. Zwróćmy uwagę na rzadko podkreślane w przekazie naukowym usytuowanie patriarchatów: cztery wschodnie, jeden zachodni.

63 Epist. 24; PG 120, 774.
}

nię w mnogości nie waha się jednak wypowiadać bardzo ostro brzmiących słów: „Jednocześnie milczeć nie możemy, słysząc, iż duchowieństwo Konstantynopola zwykło pogardzać (oneididzesthai) Eklezją Rzymską". Źródłem tej „pogardy”, a zarazem znacznego sporu była kwestia materii sakramentu Eucharystii, a zwłaszcza jakości stosowanego w Niej chleba.

Sakramentalny kontekst każe spojrzeć na jego naturę nieco inaczej. W opracowaniach spotyka się stwierdzenia, iż kontrowersje między Wschodem a Zachodem dotyczące analogicznie zastosowania chleb na zakwasie lub chleba przaśnego należały do rzędu niewiele znaczących dyskusji. Wydaje się jednak, iż dyskusje te nie były pozbawione ważkiego, teologicznego sensu: chodziło wszak o Najświętszy Sakrament, pryncypialne źródło zbawienia, podstawę zaistnienia jedności eklezjalnej, co więcej, podstawy zaistnienia Kościoła widzialnego, Eklezji, Która działa niby kapłan tego świata i całej natury, jednakże znajdując swe powiązanie z Niewidzialną Społecznością Zbawionych.

Cud kościelnego zgromadzenia polega na tym, iż jest ono Chrystusowym Ciałem, gdyż Chrystus przebywa w swoich członkach, sprawiając, iż wierni są w Chrystusie, a On przebywa w nich ${ }^{64}$. Dzięki Niemu Ciało Niewidzialnego Kościoła i Eklezji konkretyzuje się w Chlebie, prawdziwym Ciele Pańskim, pokarmie wieczności. W tym kontekście pytanie o jakość tego chleba nie wydaje się bezzasadne.

Eucharystia to także symbol zjednoczenia $\mathrm{w}$ jednej Eklezji, podstawa jedności, przeto, jak się wydaje, autentyczną jest deklaracja patriarchy weneckiego: „A my byśmy bardzo pragnęli jedności eklezjalnej, by w schizmę nie popaść jakową, przeto właśnie chleba przaśnego strzec będziemy, gdyż nie wywodzi się on tylko ze zwyczaju apostolskiego, lecz jest najpełniejszą forma kontynuacji Pańskiego zwyczaju /.../ Albowiem zmieszanie mąki i kwasu chlebowego, jak to ma miejsce w Eklezji Wschodniej, odnosi się do natury Wcielonego Słowa; prosta zaś masa niekwaszona /.../ przedstawia czystość Ciała"65.

Głową tego Ciała jest Chrystus. Jego czystości nie da się zakwestionować. Lecz tak liczne członki charakteryzują się grzesznością, a więc nieczystością, nie mając jednak wpływu na Świętość Głowy. Jest On ponad członkami, eo ipso ponad prawami natury.

W związku z tym nie bez znaczenia jest uzasadnienie też wschodniej praktyki sprawowania Eucharystii na chlebie kwaszonym - przedstawiciele Ortodoksji, aczkolwiek od Chrystusa otrzymali Naukę, postępują nawet wbrew swoim Ojcom Kościoła, którzy nigdy nie wspominali o chlebie kwaszonym jako materii eucharystycznej ${ }^{66}$.

Patriarcha Cerulariusz zadziwił się wielce tak zarysowaną sytuacją, pewny że Ortodoksja „trzyma się prawdziwej nauki o Trójcy Świętej, podobnie jak o Wcieleniu Zbawcy naszego, Jezusa Chrystusa". Z tego powodu spieszy $\mathrm{z}$ radą do adresata: „W jednym przypadku jeno kulejesz, a mianowicie $w$ kwestii ofiary $\mathrm{z}$ chleba niekwaszonego. Bar-

\footnotetext{
64 Por. A. Schmemann, ks., Eucharystia, Białystok 1997, s. 16.

65 Epist. Dominici 3; PG 120, 753.

66 Por. Epist. Dominici 6; PG 120, 761.
} 
dzo nad tym boleje, gdyż jest to postępowanie niezgodne z eklezjalnym nauczaniem. Zgodnie za czterema patriarchatami postępujcie, za Tradycją!" ${ }^{\prime 7}$

Zasadniczym uzasadnieniem takiego stanu rzeczy jest ideowe powiązanie z ofiarą Starego Przymierza, która miała miejsce zwłaszcza w momencie realizacji paradygmatu Wieczernika, który był miejscem uczty paschalnej. Paradygmat tam zarysowany dokonywał się na podstawie chleba niekwaszonego, przeto kto uczestnicy w ofierze Chrystusa ten jednocześnie winien mieć uczestnictwo w przaśnikach Starego Przymierza. Tym wszak chlebem posłużył się Pan, co i Apostoł Narodów potwierdza ${ }^{68}$. Także dla Hebrajczyków chleb niekwaszony jest pamiątka pospiesznej ucieczki z Egiptu, przypomnieniem znaków niezwykłych i cudów wydarzeniu temu towarzyszących. Ponadto chleb jeno przed zakwaszeniem może być doskonałą żertwą, dzięki konsekracji stając się Ciałem Chrystusa ${ }^{69}$.

W dalszej części pisma Patriarcha odwołuje się do ortodoksyjnego poglądu, jakoby chleb przaśny był martwy i pozbawiony duszy, nie może więc stać się pełnoprawnym, konsekrowanym Ciałem Pana, ożywa zaś po dodaniu doń kwasu chlebowego i wody. Takie ujęcie kwestii prowadzić może do stwierdzenia, iż zachowanie Chrystusa i wszystkich sprawujących Nową Paschę jest absurdalne, bo ich działanie nie sprawia żadnego skutku sakramentalnego! Zbędna tedy byłaby również adoracja tak pojmowanego sakramentu, zbędna też i uczta ${ }^{70}$ ! Błądzisz, Bracie, konkluduje teolog prawosławny, a utwierdzając się w błędzie, ku niebezpieczeństwu utraty zbawienia zmierzasz ${ }^{71}$ !

Swą groźbę łagodzi perswazją: zrozum, bardzo uczony mężu; jeśli w przaśniku nie ma siły witalnej w ogóle, to jakże można by ja utracić? A siła ta nie w samym chlebie jest ukryta. Odwołując się do św. Jana Teologa, uzupełnia: Trzej są żyjący, co życie dają spożywającym: Duch, woda, $\mathrm{krew}^{72}$.

Pojmowanie sakramentu Eucharystii jako szczególnego miejsca realizacji duchowego działania poprzez znaki wody i krwi stanowi pewne novum w dziedzinie rzymskokatolickiej sakramentologii, w szczególny bowiem sposób kładziono nacisk na ofiarniczy, chrystocentryczny jej charakter. Tymczasem patriarcha podkreśla, iż ofiara ta jest dziełem Ducha Świętego, obecnego podczas wielkopiątkowej Męki, Swą obecnością konsekrujący wypływające z boku Pańskiego potwierdzające autentyczność śmierci znaki odkupienia.

Twierdzono, kontynuuje patriarcha, iż tradycja judaistyczną nakazywała stosować też chleb kwaszony w bardzo

\footnotetext{
67 Por. Epist. Cerularii, 7; PG 120, 763-764.

68 Por. 1 Kor $11,23 n$;

69 Por. Epist. Cerularii 8; PG 120, 764.

70 W dobie średniowiecza w Eklezji rzymskokatolickiej dokonało się bardzo istotne przewartościowanie w sferze pobożności eucharystycznej - miejsce uczestnictwa w Uczcie Pańskiej zajęła adoracja Najświętszego Sakramentu. Wspaniałe ołtarze miały wspomagać duchowe przeżywanie tejże, Sanctissimum przeniesiono z zakrystii, gdzie był wcześniej przechowywany do specjalnej kaplicy adoracyjnej itp.

71 Por. Epist. Dominici 9; PG 120, 764

72 Por. 1 J 5,8.
}

często składanych ofiarach pokarmowych ${ }^{73}$. Już dłużej nie jesteśmy pod Prawem, w Chrystusie jesteśmy Stworzeniem Nowym $^{74}$ !

„O, nieszczęsny ja człowiek! Łzami żałości się zalewam, ilekroć wspomnę, jak wiele Błogosławiony Pan znosić musi od tych, co się na Imię Chrystusa powołują, chwaleni za własne swe czyny być pragną /.../ niby grobowcami pobielanymi za żywota będąc. Szczęśliwie na straży Eklezji stoi ten, co na Stolicy Rzymskiej zasiada, nie zgadzając się, by celebrować wespół z pozostałymi patriarchami, słusznej trzymając się drogi” - konkluduje swój zasadniczy wykład eucharystyczny Patriarcha Konstantynopola ${ }^{75}$.

Przedstawienie kontrowersyjnej postawy przez pryzmat konkretnego dokumentu wydaje się bardzo interesujące. Pozwalając przemawiać pismom z epoki jednocześnie możemy konkretnie zrozumieć, na czym polegała polemika, dyskusja, wspólne dochodzenie do konsensu. Eucharystia to podstawa życia eklezjalnego, więc próby jak najdoskonalszego jej przedstawienia, a co za tym idzie i przeżywania, stanowią istotny wkład w zasadniczy rozwój Eklezji, pragnącej obecnie oddychać „dwoma płucami Wschodu i Zachodu".

\section{Kontrowersyjna klątwa}

Wydarzenia osiągały swe apogeum. Legaci papiescy przybywając do Konstantynopola mieli wyrazić negatywne stanowisko papieża, który już nie żył, acz przed śmiercią zlecił im swe pełnomocnictwo. Zgodnie ze starożytną zasadą, pełnomocnictwo obowiązuje do momentu ostatniej chwili ziemskiego życia człowieka. Oto kontrowersja pierwsza.

Legaci dysponowali papieskim dokumentem, mającym pełnić rolę bulli ekskomunikującej, w bardzo więc jednoznaczny sposób poniżający Ortodoksję. Papież Leon IX uważał Ją za jedną z sekt, rodzajowo takich samych jak arianie, co chcą chrzcić na nowo w trynitarnej wierze ochrzczonych, czy donatyści, prawdziwą ofiarę Chrystusa za nic mający. Ortodoksja, zdaniem papieża, podobna jest nikolaitom, jeszcze z apokaliptycznego Listu do Efezu znanym. Aby lepiej zrozumieć przesłanie papieskie, zapytajmy, kim byli.

Według św. Hilarego z Poitiers, założycielem nikolaitów miał być prozelita z Antiochii, diakon Mikołaj, jedyny z Siedmiu pochodzenia nie żydowskiego. Św. Klemens Aleksandryjski prostuje jednak tę informację ${ }^{76}$, uznając, iż o założycielu niewiele wiemy ${ }^{77}$. Sekta wywodziła się z gnostyków, czyli badaczy jakości duchowego poznawania,

\footnotetext{
73 W tym wypadku nastąpiło nieporozumienie: w każdym przypadku, gdy chodziło o chleb ofiarniczy, był to chleb niekwaszony. Podobnie i tzw. chleby pokładne, czyli przygotowane do spożycia na wypadek trudnej sytuacji wyłącznie przez samych kapłanów.

74 Por. $R z 6,14$.

75 Por. tamże, 12; PG 120,768.

76 PG 8, 1130.

77 Jednakże współcześni autorzy (np. Herne Masson, Słownik herezji w Kościele katolickim, s. 227) opierają się wyłącznie na informacji św. Hilarego.
} 
a głównym jej hasłem, usprawiedliwiającym stosowaną przez nich rytualną rozwiązłość miało być zawołanie założyciela: „ćwicz ciało”, co następcy rozumieli jako używanie ciała tak intensywnie, by doprowadzić je do wyczerpania ${ }^{78}$. Euzebiusz z Cezarei, pierwszy historyk podaje, iż sekta nie istniała długo ${ }^{79}$.

W bulli papież nie waha się porównać Ortodoksji nawet do kobiety, co z powodu miesiączki, czy to z uwagi na bóle porodowe popada w nieczystość ${ }^{80}$. Uwagi papieża nie uchodzi nawet to, iż duchowieństwo prawosławne nie goli bród, co uznaje za wynaturzenie judaistycznej praktyki nazireatu $^{81}$.

„Z tego powodu, głosi Leon IX, mając do czynienia z niezmiernymi błędami, pomimo wcześniejszych upomnień wysyłamy nuncjuszy, którzy na argumenty tak dokonującego się zła, rozumnością odpowiedzą tym, co odmienne stanowisko zajmują", a umiejętnie wszelakie argumenty zbić będą mogli i do opamiętania, niezbędnego do zniesienia kary, doprowadzą. /.../ Przeto i my, z pozycji pierwszej i apostolskiej stolicy tak znaczącej nieprawości znieść nie mogąc, /.../ mocą Najświętszej i Niepodzielnej Trójcy, z Apostolskiego Tronu, którego daremnie oskarżać, wszystkich przewodników Ortodoksji ${ }^{82}$, na mocy siedmiu soborów powszechnych i całej Katolickiej Eklezji anatemą okładamy, nie szczędząc przy tym apostolskiej troski, Michała i tych, co z nim się jednoczą ${ }^{83}$, a przekonania naszego przejąć nie chcą..." 84 .

Przeczuwając nadciągające zło, patriarcha Michał tak się skarży do biskupa Piotra z Antiochii: „Przed niejakim czasem kilku starszych z Rzymu, wyposażonych w pełnomocnictwa, odpowiednie pouczenia i wiedzę o Ortodoksji przez papieża im przekazaną, z uwagi na zgorszenia wynikające z systemu prawd ortodoksyjnych, do wspólnego, zgodnego wyznawania wiary nas nakłaniać jęli, prosząc też się dołączyć do wyprawy przeciwko Frankom. Zarówno ten list, jak i jego przekład ${ }^{85}$ przekazaliśmy imperatorowi, by po podpisaniu do nas powróciły" ${ }^{86}$.

Zwrócono się do znanego nam już Argyra, który w krótkim czasie list ten przetłumaczył, liczne przekłamania w nim popełniając. "Zaprawdę, wielki to nauczyciel, a wierny religii swojej - komentuje patriarcha, - złe żywiący

\footnotetext{
78 Por. tamże.

79 PG 20, 275. Zwięzłe, acz z patrystycznymi odwołaniami omówienie hasła nikolaici znajdziemy w: Podręczna Encyklopedia Biblijna pod redakcją ks. Eugeniusza Dąbrowskiego, Poznań 1959,t. II, s. 161 - 162. Zapewne formalne istnienie sekty nie było długie, być może trzy wieki, jednak wzmianka o niej w dokumencie z wieku XI może potwierdzać jej obecność w świadomości wierzących, zwłaszcza na Zachodzie, dla których, co widać po przytoczonym porównaniu, odwołanie do niej symbolizować mogło najbardziej niewłaściwy sposób pojmowania wiary. Tekst bulli papieskiej zawarto w PL 143, 741-769..

80 Por. PL 143, 743. Papież odwołuje się tu do Prawa Mojżeszowego.

${ }^{81}$ Tamże. Nazireat w judaizmie był znakiem całkowitego poddania się i oddania Bogu, wyrażonego zwłaszcza unikaniem golenia się i całkowitego zakazu strzyżenia włosów na głowie.

82 W oryginale orthodoxorum patrum, czyli ojców Ortodoksji, zapewne przewodników duchowych tego wyznania.

83 Dosłownie tych, co za nim idą, sequaces.

84 PL 143,743

85 Na grekę

${ }^{86}$ EpistolaMichaelis Patriarchae ad Petrum in Antiochia 3; PG 120, 784.
}

uczucia wobec Miasta i Imperium, także w tym przypadku zwyczaju swego nie odstąpił, pieniądze przyjmując, a dla siebie je przeznaczajac" $" 87$. Argyrus na tym nie poprzestał, spotykając się z legatami podjął nawet próbę zwołania czegoś w rodzaju synodu biskupów ${ }^{88}$, z których jeden okazał się być z urzędu swego zrzuconym i na pięć lat wydalonym $\mathrm{z}$ granic Imperium ${ }^{89}$.

Gdy legaci przybyli do miasta cesarskiego, chcieli się najpierw spotkać z imperatorem, zachowując się wszelako „W bardzo arogancki sposób. Żadnego pozdrowienia, żadnego skłonu głowy na powitanie! Potem się miedzy sobą nad czymś naradzali" "90. Nic niemal nie mówiąc, swe listy nam przekazali i natychmiast wyszli. Skromność nasza listy owe przejrzała, pieczęcie ich złamawszy, badając dokładnie, a z treścią się zapoznając. Dotyczyła zaś ona tego, o co Argyrus, przebywając w naszym mieście często mnie zahaczał, a mianowicie o przaśniki"91.

Dalsze wydarzenia spopularyzowano na podstawie dzieła kardynała Humberta, głównego wykonawcy woli papieskiej, Brevis et succinta commemoratio, (PL 143, 10011004), gdzie znajdują się wszystkie szczegóły ranka sobotniego 16 lipca 1054 roku, tuż przed rozpoczęciem świętej Liturgii w konstantynopolskiej Hagia Sophia.

Oto komentarz patriarchy Michała Cerulariusza: „Nigdy jeszcze demony tak się nie rozsierdziły, jako w obecnym czasie. A wydaje się nie mieć końca ich działalność. Gdy napierając na pobożnych ludzi, nowe prawdy, w umysłach swoich powstałe, wciąż forsują, stąd też liczne zafałszowania dotyczące Wcielenia Pańskiego się mnożą, z czego i błędy rozliczne powstają" ${ }^{92}$...

$\mathrm{Na}$ zakończenie warto zająć stanowisko w kilku kwestiach kontrowersyjnych:

- legaci z uwagi na śmierć papieża nie mieli prawa do realizacji swej misji;

- z tego samego powodu kardynał Humbert, ogłaszając bullę ekskomunikującą, dokonał prawnego nadużycia;

- ekskomunika ze strony papieskiej obejmowała wyłącznie patriarchę Michała i jego najbliższe otoczenie, ekskomunika patriarsza zaś skierowana była wyłącznie przeciw papieżowi, stąd $\mathrm{z}$ racji jego zgonu nieskuteczna;

- z wymienionych wyżej powodów wydarzenia roku 1054 miały charakter lokalny, z natury rzeczy ekskomuniki nie mogły objąć całych wyznań, gdyż żadna kara kościelna takiej mocy nie posiada.

Na okresie „złotego wieku Bizancjum” pojawiła się pierwsza rysa, jedności kościelnej nic jednak nie jest w stanie naruszyć...

\footnotetext{
87 Epist. Michaelis 4; PG 120, 784.

88 Do czego zresztą na mocy chrztu miał prawo.

89 Por. Epist. Michaelis 5; PG 120, 785. Informacja chyba niedość ścisła.

90 Tamże, 6, PG 120, 786.

91 Tamże 7, PG 120, 787.

92 Fragment bulli potępiającej autorstwa patriarchy Michała Cerulariusza, zawarta w Edyktach Synodalnych (PG 120, 737).
} 


\section{Bibliografia}

\section{Fontes}

Leonis Noni Papae Adversus Graecorum calumnias (false titulatum Dialogus inter Romanum et Contantinopolitanum), PL 143, 744-769;

Cerularii epistola ad Joannem Tranensem in Apulia sive ad ipsum papam Leonem IX, (latinisatus cardinale Humberto, episcopo Silvae Candidae), PG 120, 755-782;

Cerularius, Ad Petrum de Antiochia, PG 120, 781-796;

Epistola ad Petrum in Antiochia, PG 120, 781-796;

Epistola Petri Theopoleos, totius Orientis patriarchae dissertatio, eo tempore scripta, qua advenit Italus Argyrus et nostra reprehenderet, PG 120, 795-816;

Epistola (secunda) ad Petrum, patriarcham Antiochenum, PG 120, 815-820;

Humbertus de Silva Candida, card., Brevis et succinta commemoratio, PL 143, 1002-1004;

Leo IX, Papa, Epistola XIX, PL 143, 758;

Ipse, Epistola XX, PL 143, 764.

Ipse, Epistola centesima od Michaelem Const., PL 143, 744-769;
Leo de Ochrida, Epistola ad Joannem Episcopum Tranesensem, PG 120, 836-838;

Nicetas chartophylax Nicaenus, Quibus temporibus et quarum criminationum causa a Const. Ecclesiam sejunxerit se Romanorum Ecclesia, PG 120, 713-720;

\section{Gravissima elaborata}

Gay J., L'Italie Meridionale et l'Empire Byzantine (867-1071), Paris 1904;

Haldon J., Warfare, State and Society in the Bizantine World 5651204, Oxford 1999;

Przekop E., sac., Rzym - Konstantynopol . Na drogach podziału i pojednania, Olsztyn 1987;

Runciman S., Schizma Wschodnia, przekład Jan Gawroński, Warszawa 1963;

Schmemann A., sac., Eucharystia, Białystok 1997;

Tomczak R., sac., Eklezjogeneza w interpretacji wspótczesnych polskich teologów, Studia Paradyskie, XVI / 2006, s. 179 - 195 [versio electronica];

Rozmiar artykułu: 1,8 arkusza wydawniczego 